\title{
Unicellular versus Filamentous: The Glacial Alga Ancylonema alaskana comb. et stat. nov. and Its Ecophysiological Relatedness to Ancylonema nordenskioeldii (Zygnematophyceae, Streptophyta)
}

\author{
Lenka Procházková $^{1, *(\mathbb{D})}$, Tomáš Rezanka $^{2} \mathbb{D}$, Linda Nedbalová ${ }^{1,3}$ (D) and Daniel Remias ${ }^{4, *(\mathbb{D})}$ \\ 1 Department of Ecology, Faculty of Science, Charles University, Viničná 7, 12844 Prague, Czech Republic; \\ lindane@natur.cuni.cz \\ 2 Institute of Microbiology, The Czech Academy of Sciences, Vídeňská 1083, 14220 Prague, Czech Republic; \\ rezanka@biomed.cas.cz \\ 3 Centre for Phycology, Institute of Botany of the Czech Academy of Sciences, Dukelská 135, 37982 Třeboň, \\ Czech Republic \\ 4 School of Engineering, University of Applied Sciences Upper Austria, Stelzhamerstr. 23, 4600 Wels, Austria \\ * Correspondence: lenkacerven@gmail.com (L.P.); daniel.remias@fh-wels.at (D.R.); Tel.: +420-221-95-1809 (L.P.); \\ +43-5-0804-44479 (D.R.)
}

check for updates

Citation: Procházková, L.; Řezanka,

T.; Nedbalová, L.; Remias, D.

Unicellular versus Filamentous: The Glacial Alga Ancylonema alaskana comb. et stat. nov. and Its

Ecophysiological Relatedness to

Ancylonema nordenskioeldii

(Zygnematophyceae, Streptophyta).

Microorganisms 2021, 9, 1103.

https://doi.org/10.3390/

microorganisms 9051103

Academic Editor:

Fernando Puente-Sánchez

Received: 23 April 2021

Accepted: 17 May 2021

Published: 20 May 2021

Publisher's Note: MDPI stays neutral with regard to jurisdictional claims in published maps and institutional affiliations.

Copyright: (c) 2021 by the authors. Licensee MDPI, Basel, Switzerland. This article is an open access article distributed under the terms and conditions of the Creative Commons Attribution (CC BY) license (https:/ / creativecommons.org/licenses/by/ $4.0 /)$.
Abstract: Melting polar and alpine ice surfaces frequently exhibit blooms of dark pigmented algae. These microbial extremophiles significantly reduce the surface albedo of glaciers, thus accelerating melt rates. However, the ecology, physiology and taxonomy of cryoflora are not yet fully understood. Here, a Swiss and an Austrian glacier dominated either by filamentous Ancylonema nordenskioeldii or unicellular Mesotaenium berggrenii var. alaskanum, were sampled. Molecular analysis showed that both species are closely related, sharing identical chloroplast morphologies (parietal-lobed for Ancylonema vs. axial plate-like for Mesotaenium sensu stricto), thus the unicellular species was renamed Ancylonema alaskana. Moreover, an ecophysiological comparison of the two species was performed: pulse-amplitude modulated (PAM) fluorometry confirmed that they have a high tolerance to elevated solar irradiation, the physiological light preferences reflected the conditions in the original habitat; nonetheless, A. nordenskioeldii was adapted to higher irradiances while the photosystems of A. alaskana were able to use efficiently low irradiances. Additionally, the main vacuolar polyphenol, which effectively shields the photosystems, was identical in both species. Also, about half of the cellular fatty acids were polyunsaturated, and the lipidome profiles dominated by triacylglycerols were very similar. The results indicate that $A$. alaskana is physiologically very similar and closely related but genetically distinct to $A$. nordenskioeldii.

Keywords: cryoflora; supraglacial communities; photosynthesis; lipidome; fatty acids; polyphenols; Mesotaeniaceae; phylogeny

\section{Introduction}

Melting glaciers harbor diverse communities of specialized microorganisms [1], and the habitat can be regarded as extreme for photoautotrophic life, considering the prevailing conditions [2,3]. Significant abiotic parameters are excessive irradiation, limited nutrients, permanently low temperature and diurnal freeze-thaw cycles on bare ice. The current knowledge about biodiversity, distribution and adaptations of glacial algae were reviewed in [4]. Generally, these habitats are dominated by few zygnematophycean species. Most common are Mesotaenium berggrenii var. alaskanum and Ancylonema nordenskioeldii (Zygnematophyceae, Streptophyta). Both species are closely related but morphologically distinguishable, the first being more roundish after cell cleavage and practically unicellular [5,6]; the latter cylindrical-elongate and forming filaments [7]. They are apparently cosmopolitan in polar and mid-latitude mountainous regions [8,9]. In addition, 
Cylindrocystis is a third zygnematophycean genus with members causing or participating in glacial blooms, and cells can be distinguished by cell size, shape and chloroplast morphology [10]. Cytologically, all of these species share abundant brownish phenols in vacuoles; the main constituent, a glycosylated purpurogallin derivative pigment, is believed to play a significant role for tolerating high visible and ultraviolet irradiance, thus preventing either photoinhibition or DNA mutation effects [11,12]. During summer, blooms of glacial algae, in combination with cryoconite and inorganic particles, reduce the albedo of glacier surfaces, consequently accelerating melting, even affecting scenarios of global sea-level rise in the long term [13-16]. This "dark ice" phenomenon is of extraordinary significance in the Western Greenland Ice Sheet [17].

The aim of this study was to explore similarities and differences between M. berggrenii var. alaskanum and A. nordenskioeldii from the European Alps. To this end, field populations dominated either by the first in Austria [6] or the later in Switzerland (recently described by [18]) were investigated. The taxonomic relatedness was evaluated by $18 \mathrm{~S}$ rDNA and $r b c \mathrm{~L}$ marker sequences, resulting in a retyping of the widespread unicellular species. This was complemented by comparing the light-dependent photophysiological performance and the cellular fatty acid and lipidomic profiles. Moreover, the phenolic pigment already characterized for M. berggrenii var. alaskanum [11] was analysed in A. nordenskioeldii as well. In general, we hypothesized on the one hand, that the physiology of both species should be similar. On the other hand, both morphotypes represent independent species, despite the fact that both algae commonly (but not necessarily) occur together in virtually all glaciated regions of the world.

\section{Materials and Methods}

\subsection{Harvest and Field Measurements}

Table 1 shows the collection details for Mesotaenium berggrenii var. alaskanum and Ancylonema nordenskioeldii. The presence and species composition of glacial algae were evaluated by an Evolution Portable Field Microscope (Ted Pella, Redding, CA, USA) at $400 \times$ magnification. Harvest took place with ice axes, ice saws and stainless-steel shovels by scrapping off the uppermost 1 to $2 \mathrm{~cm}$ of surface ice into 101 buckets for transportation to the lab. The prevailing irradiance at the time of sampling was recorded for Morteratsch Glacier at an elevation of approximately $2300 \mathrm{~m}$ a.s.l. with PMA2100 logger (Solar Light Company, Glenside, PA, USA) using visible (VIS, PMA2131), ultraviolet-A (UVA, PMA2111) and UVB (PMA2106) sensors, placed $50 \mathrm{~cm}$ above the ice surface. $\mathrm{pH}$ and electrical conductivity were obtained with WTW instruments (Cond 340i Inolab, Weilheim, Germany).

Table 1. Glacial algal sample codes, collection date, sampling sites, elevation (in meters above sea level) and geographic position (GPS).

\begin{tabular}{ccccc}
\hline Sample & Harvest & Glacier & Elevation & GPS \\
\hline P39 & 6 September 2006 & Tiefenbach Ferner, AT & 3000 & $46^{\circ} 55^{\prime} \mathrm{N} 10^{\circ} 56^{\prime} \mathrm{E}$ \\
WP167 & 30 August 2017 & Gurgler Ferner, AT & 2728 & $46^{\circ} 48.280^{\prime} \mathrm{N} 10^{\circ} 58.804^{\prime} \mathrm{E}$ \\
WP210 & 22 August 2018 & Morteratsch Glacier, CH & 2211 & $46^{\circ} 24.999^{\prime} \mathrm{N} \mathrm{9} 56.021^{\prime} \mathrm{E}$ \\
WP211 & 22 August 2018 & Morteratsch Glacier, CH & 2275 & $46^{\circ} 24.847^{\prime} \mathrm{N} \mathrm{9} 56.032^{\prime} \mathrm{E}$ \\
WP213 & 24 August 2018 & Morteratsch Glacier, CH & 2161 & $46^{\circ} 25.195^{\prime} \mathrm{N} 9^{\circ} 55.913^{\prime} \mathrm{E}$ \\
WP249 & 18 August 2020 & Morteratsch Glacier, CH & 2203 & $46^{\circ} 25.075^{\prime} \mathrm{N} 9^{\circ} 55.985^{\prime} \mathrm{E}$ \\
WP251 & 25 August 2020 & Gurgler Ferner, AT & 2727 & $46^{\circ} 48.327^{\prime} \mathrm{N} 10^{\circ} 58.739^{\prime} \mathrm{E}$ \\
\hline
\end{tabular}

\subsection{Cell Cleaning, Storage and Microscopy}

With a field microscope, virtually monospecific blooms (P39, WP211, WP167 and WP251) were harvested according to [19]. Additionally, three mixed algal snow communities (WP210, WP249, WP213) were included in this study to describe cell size ranges of the two studied glacial algal species. Harvested glacial ice was placed in $10 \mathrm{~L}$ bucket. The glacier ice was gently melted in the dark at $4{ }^{\circ} \mathrm{C}$ over night. In the first step, larger debris was removed by sieving the meltwater through 800, 400, 200 and $140 \mu \mathrm{m}$ mesh size 
stainless steel sieve tower (Retsch, Germany). Samples WP211 and WP167 were subject of Sanger sequencing, pulse-amplitude modulated (PAM) fluorometric measurements and lipidomic analysis. Samples WP211 and WP251 were used for fatty acid analysis and cultivation assays.

To separate glacial algae from other microscopic objects like pollen, yeast, protozoa or other algae, a density gradient with Percoll (Merck P1644; layers of 50, 75 and 100\% concentration, $v / v)$ was performed and centrifuged $\left(400 \times g, 10 \mathrm{~min}\right.$ at $\left.1{ }^{\circ} \mathrm{C}\right)$. The glacial algae accumulated at the $75 \%$ to $100 \%$ Percoll interface, were transferred with a syringe into a new centrifugation tube, and washed and centrifuged twice with sterile-filtered (Whatman GF/F) meltwater. Cleaned cells were stored at 2 to $4{ }^{\circ} \mathrm{C}$ prior cultivation assays at an illumination of approximately $40 \mu \mathrm{mol} \mathrm{PAR} \mathrm{m}^{-2} \mathrm{~s}^{-1}$.

Cells were observed with a Nikon Eclipse 80i light microscope equipped with a Nikon DS-5M camera (Nikon Instruments, Amsterdam, Netherlands) for bright field and with a Zeiss Axiovert 200M for fluorescence. Cell concentrations were calculated based on counting with a Plankton Chamber acc. to Kolkwitz (Hydro-Bios, Altenholz, Germany).

\subsection{Cultivation Assays}

For obtaining strains of $A$. nordenskioeldii (WP211) and M. berggenii var. alaskanum (WP251), $10 \mu \mathrm{L}$ aliquots of cells from glacial meltwater were inoculated on $1.7 \%(w / v)$ agar plates with synthetic freshwater medium (SFM, https: / / www.uni-due.de/biology/ccac/ growth_media_sfm.php (accessed on 27 August 2020)) and incubated at approximately $5 \mu \mathrm{mol} \mathrm{PAR} \mathrm{m}^{-2} \mathrm{~s}^{-1}$ irradiance at a diurnal regime of $12 \mathrm{~h}$ light/darkness at $4{ }^{\circ} \mathrm{C}$.

\subsection{Molecular Characterisation}

DNA isolation out of the unialgal field samples WP211 and WP167 was carried out with a DNeasy Plant Mini Kit (Qiagen, Germany), as in [20]. The 18S small subunit ribosomal RNA gene (18S rDNA) and ribulose-1,5-bisphosphate carboxylase/oxygenase large subunit $(r b c \mathrm{~L})$ marker regions were amplified from DNA isolates by polymerase chain reaction (PCR) using existing primers (Table S1). Amplification reactions were described in [20]. PCR products were purified and sequenced using an Applied Biosystems automated sequencer (ABI 3730xl) at Macrogene Europe (Amsterdam, The Netherlands). The obtained sequences were submitted to NCBI Nucleotide sequence database (accession numbers of Ancylonema nordenskioeldii WP211: 18S rDNA-MW922838, rbcL-MW922839; Ancylonema alaskana WP167: rbcL-MW922840).

\subsection{Phylogenetic Analysis}

Two different alignments were constructed for the phylogenetic analyses, based on the $18 \mathrm{~S}$ rRNA and $r b c \mathrm{~L}$ gene sequences. The sequences were selected according to $[10,11,21]$ to encompass all the zygnematophycean lineages. The $18 \mathrm{~S}$ rDNA alignment contained 56 sequences (1777 bp), the $r b c L$ matrix consisted of 49 sequences (1290 bp); Embryophytes (Sphagnum palustre, Phaeoceros laevis, Marchantia polymorpha) were selected as the outgroup. The best-fit nucleotide substitution model was estimated by jModeltest 2.0.1 [22]. Based on the Akaike information criterion, the $\operatorname{TrN}+\mathrm{I}+\mathrm{G}$ and GRT + I + G model was selected for $18 S$ rDNA and $r b c \mathrm{~L}$, respectively. The $18 \mathrm{~S}$ rDNA and $r b c \mathrm{~L}$ phylogenetic trees were inferred by Bayesian inference (BI) and maximum likelihood (ML) according to [23], with the minor modification that Markov Chain Monte Carlo runs were carried out for three million generations in BI. Convergence of the two cold chains was checked by the average standard deviation of split frequencies of 0.001262 and 0.001563 . Bootstrap analyses and Bayesian posterior probabilities were performed as described by [23].

\subsection{Photosynthesis}

The light-dependent performance of photosystem II was measured with the unialgal field samples WP167 and WP211 (for sample processing see the Section 2.2). To gain sufficient biomass, cells were concentrated by passive sedimentation of melt water in a 
$1 \mathrm{~L}$ plastic cylinder at low light conditions at $4{ }^{\circ} \mathrm{C}$ overnight and the pellet was then used for measurements. Prior measurement, algae were kept in the glacial meltwater in the dark for $30 \mathrm{~min}$. In vivo chlorophyll fluorescence parameters were obtained with a pulseamplitude modulated fluorometer (PAM 2500, HeinzWalz GmbH, Pfullingen, Germany) in a $0.6 \mathrm{~mL}$ chamber thermostated to $1^{\circ} \mathrm{C}$. To obtain the relative electron transport rates (rETR), the apparent quantum yield for electron transport (alpha) and the light saturation point $\left(I_{k}\right)$, cells were exposed to photon flux densities (PFD) of 5, 9, 34, 67, 104, 201, 366, 622, $984,1389 \mu \mathrm{mol}$ photons $\mathrm{m}^{-2} \mathrm{~s}^{-1}$ for $30 \mathrm{~s}$ each. Four independent replicates were measured. For further technical details, see [20].

\subsection{Analysis of Phenols}

The phenolic compounds of $A$. nordenskioeldii were extracted and analysed according to [11]. Briefly, 20\% ethanol extracts were characterized by liquid chromatography mass spectrometry (LC-MS) with an Agilent ChemStation 1100, equipped with a Synergy Hydro column $4 \mu \mathrm{m}$ column (Phenomenex) and a diode array detector set at $280 \mathrm{~nm}$, coupled with an Esquire 3000plus mass spectrometer with electrospray ionization (Bruker Daltonics, Bremen, Germany).

\subsection{Isolation and Fractionation of Lipids}

The extraction procedure was based on the method of [24], with modification as previously described [25]. Briefly, the lyophilized cells were suspended in a dichloromethanemethanol mixture $(2: 1, v / v)$ for 30 min with stirring, after which dichloromethane and water were added and the dichloromethane phase was evaporated to dryness under reduced pressure. Total lipids were dissolved in the mobile phase (acetonitrile: 2-propanol 99:1, $v / v)$ ) for further analysis by shotgun lipidomics. Lipid classes were eluted from a Sep-Pak Vac Silica cartridge 35cc (Waters; $10 \mathrm{~g}$ normal-phase silica) by chloroform (neutral lipids), acetone (glycolipids), and methanol (phospholipids) according to [26]. All classes of lipids were saponified overnight in $10 \% \mathrm{KOH}$ in methanol at room temperature. Fatty acid methyl esters were prepared by reaction of free fatty acids with diazomethane according to [20].

\subsection{Shotgun Lipidomics}

An LTQ-Orbitrap Velos mass spectrometer (Thermo Fisher Scientific, San Jose, CA, USA), a high-resolution hybrid mass spectrometer equipped with a heated electrospray interface (H-ESI), was operated in positive and negative ionization mode. Flow injection analysis (FIA) was used for sample introduction into the H-ESI ion source. Acetonitrile/water $(50: 50, v / v)$ was used at the flow rate of $150 \mu \mathrm{L} / \mathrm{min}$. The MS scan range was performed in the Fourier transform mode and recorded within a window between 200-2000 m/ $z$. Mass spectra were acquired with target mass resolution of $R=110,000$ at $\mathrm{m} / \mathrm{z} 800$ and the ion spray voltage was set at $+3.5 \mathrm{kV}$ (in the positive ionization mode) and $-2.5 \mathrm{kV}$ (in the negative ionization mode). Both ionization modes used the following parameters: sheath gas flow, 18 arbitrary units (AU); auxiliary gas flow, 7 AU; ion source temperature, $250{ }^{\circ} \mathrm{C}$; capillary temperature, $230{ }^{\circ} \mathrm{C}$; capillary voltage, $50 \mathrm{~V}$; and tube lens voltage, $170 \mathrm{~V}$. Helium was used as a collision gas for collision-induced dissociation (CID) experiments. The CID normalization energy of 35\% was used for the fragmentation of parent ions. The MS/MS product ions were detected by the high resolution FT mode. The calibration of the MS spectrometer was undertaken with the use of a Pierce LTQ Orbitrap positive and/or negative ion calibration solution (Thermo Fisher Scientific, San Jose, CA, USA). The internal lock mass was used in mass spectra acquisition, i.e., $255.2330 \mathrm{~m} / \mathrm{z}$ $[\mathrm{M}-\mathrm{H}]^{-}$palmitic acid in the negative ESI. The mass accuracy was better than $0.9 \mathrm{ppm}$. The chemical structure of the compounds was confirmed with the help of the spectral database LIPID MAPS ${ }^{\circledR}$ Lipidomics Gateway (http:/ / www.lipidmaps.org/ (accessed on 15 December 2020)). 


\subsection{Fatty Acid Methyl Esters Analysis (FAMEs)}

The structures of fatty acid methyl esters (FAMEs) were confirmed by comparison with gas chromatography/mass spectrometry retention times and fragmentation patterns with those of standard FAMEs (Supelco, Prague, Czech Republic) [27]. Procedures were described in detail in [20].

\section{Results}

\subsection{Field Blooms}

Microalgal ice surface blooms at Morteratsch Glacier in Switzerland were mainly caused by filaments of $A$. nordenskioeldii and some scattered unicells of $M$. berggrenii var. alaskanum. In contrast, the blooms at Gurgler Ferner in Austria, which were situated approximately $90 \mathrm{~km}$ northeast from the Swiss site, consisted microscopically exclusively of M. berggrenii var. alaskanum. Based on the acquired morphological and genetic data from both field sites, the latter was moved to the genus Ancylonema and the rank of a variety is raised to species status (see below).

\subsection{Taxonomic Treatment}

Ancylonema alaskana (Kol) Procházková and Remias comb. et stat. nov. (Figure 1a-d)

BASIONYM: Mesotaenium berggrenii var. alaskanum Kol 1942, Smithsonian Miscellaneous Collections 101: pp. 25-26 (as "alaskana")

EPITYPE (here designated): The field vegetative cells (specimen WP167) deposited in a lyophilized (non-viable) state at the Culture Collection of Algae of Charles University in Prague, Czech Republic. Figure 1a show the morphology of the cells within the specimen WP167 used for the epitype.

HABITAT: polar and alpine glacial ice surfaces, occasionally in melting snow and slush.

DISTRIBUTION (based on light microscopical diagnosis): Alaska [28-30], European Alps [6,11], Svalbard [31], Greenland [17,32], Altai Mts, Russia [33], Himalaya [34], Antarctica [5].

SPECIES DESCRIPTION: Cells single or in temporary connected pairs after cell division, cell walls smooth, cells 7-11.6 $\mu \mathrm{m}$ wide and 8.1-20.6 $\mu \mathrm{m}$ long, cylindrical cell shape with apexes broadly rounded, one (or two) parietal, discoid, cup-shaped or elongatehemispherical, weakly lobed chloroplast with one pyrenoid, sometimes causing a bulge. Cytosol with central unpigmented nucleus and peripheral vacuoles, the latter occupied by characteristic dark phenols. Chloroplast division precedes cytokinesis. Sexual reproduction by conjugation between two cells results in a regular or irregular, spherical or angular to ellipsoidal zygote. DNA sequences available: nuclear 18S rDNA (JF430424) and plastid $r b c \mathrm{~L}$ (MW922840).

FIELD SAMPLES EXAMINED: WP167, WP251.

REMARKS: A. nordenskioeldii occurs in the same habitat as A. alaskana and has the same brownish vacuolar pigmentation, but differs by significantly larger cell widths and cell lengths (10.7-15.2 $\mu \mathrm{m} \times 19.6-51 \mu \mathrm{m}$; based on Swiss populations; this study), trichal habitus (filaments usually with 2 to 64 cells [7] and an irregularry oblong zygote [7]. Single cells of $A$. nordenskioeldii can be distuingished from A. alaskana in most cases by cells' size, the former reaching up to $15 \times 65 \mu \mathrm{m}$ (Greenland, figures 10, 11 in [35] or $15 \times 32-72 \mu \mathrm{m}$ (Swiss Alps, Figure 1f, this study). However, singe cells of A. nordenskioeldii can be morphologically confused with individuals of "large" $M$. berggrenii sensu [8], a taxon with an unclear status (no molecular sequence available yet). Finally, A. nordenskioeldii and A. alaskana differ in their $18 \mathrm{~S}$ rDNA and $r b c \mathrm{~L}$ molecular markers. For A. nordenskioeldii from Morteratsch Glacier, accession numbers are provided: 18S rDNA—MW922838; rbcL-MW922839.

NOMENCLATURAL REMARKS: Ancylonema nordenskioeldii var. berggrenii Wittrock (Tafel III, figure 18) [36] (三 Mesotaenium berggrenii (Wittrock) Lagerheim [37]) is a valid infraspecific name based on the articles 38.8-38.10 of the International Code of Nomenclature for algae, fungi, and plants [38]. M. berggrenii var. alaskanum should be treated as a distinct species from its type variety based on the cell morphological differences. For unambiguous 
nomenclatural identification, the proposed comb. nov. was based on the variety epithet of "alaskanum" from the basionym (reflecting the initial description from Alaska by [28]), which is here promoted as the species epithet "alaskana".
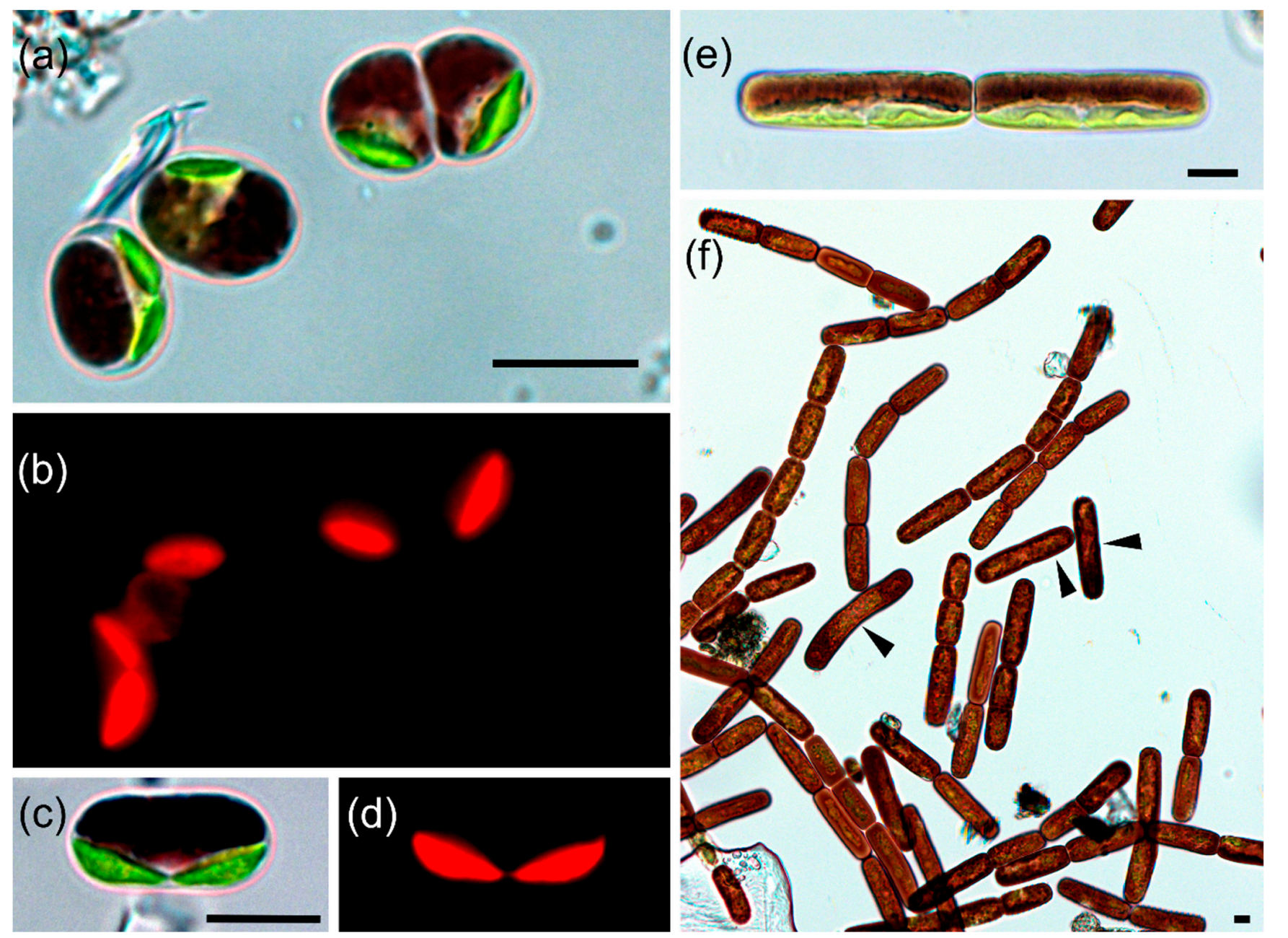

Figure 1. Light microphotographs of cells collected from melting glacier surfaces in the European Alps, (a-d) Ancylonema alaskana comb. et stat. nov. (WP167) and (e,f) Ancylonema nordenskioeldii (WP211). (a) transient stage of two cells after cleavage (upper right), showing one parietal chloroplast per cell in the side view (upper right and middle) or two chloroplasts before cell cleavage (lower left) (WP167), (c) elongated cell with two chloroplasts, (a-d) corresponding bright field and fluorescence images, the latter reveal the partly lobed chloroplast shape. (e) side view demonstrating two parietal chloroplasts per cell (or one with two pyrenoids), (f) group of dark pigmented filaments, most of them with 2, 4 or 8 cells, but also single individuals were present (arrowheads). Scale: $10 \mu \mathrm{m}$.

\subsection{Habitat Conditions, Population Densities and Cell Sizes of Glacial Algae}

The glacier communities and the habitat parameters between the Austrian and the Swiss site were compared. At Gurgler Ferner (Austria), the sampling sites were at the lower, snow-free and flat parts of ice where greyish to purple surface blooms were observed during August 2017 and 2020 (Figure S1a), with cells of A. alaskana (Figure 1a-d). The meltwater pH was 5.3 and the EC $4.3 \mu \mathrm{S} \mathrm{cm}^{-1}$. At Morteratsch Glacier (Switzerland), a similar situation was found in August 2018 and 2020 (Figure S1b) and was dominated by A. nordenskioeldii (Figure 1e,f), comprising usually of 2 to 8 cells per filament (longest observed filament was 16 cells), and the meltwater had a $\mathrm{pH}$ of 6.1 and an $\mathrm{EC}$ of $4.4 \mu \mathrm{S} \mathrm{cm}{ }^{-1}$. At 12:50 h Central European Time, the following irradiance values were recorded at Morteratsch Glacier (during sunshine): photosynthetically active radiation (PAR): $2113 \mu \mathrm{mol}$ photons 
$\mathrm{m}^{-2} \mathrm{~s}^{-1}$, UV-A: $4.55 \mathrm{~mW} \mathrm{~cm}^{-2}$ and UV-B: $0.158 \mathrm{~W} \mathrm{~m}^{-2}$. While A. alaskana was present at both glaciers, filaments of $A$. nordenskioeldii were not found at Gurgler Ferner. Additionally, a few filaments morphologically addressable as Ancylonema nordenskoeldii var. chodatii were present at Morteratsch Glacier (Figure S2). In all cases, the cytosol was abundantly occupied by brownish pigmented vacuoles. Abundances and cell sizes are summarized in Table 2. The maximum population densities were quite similar on both glaciers. Generally, the cell width showed less variations, while cell lengths showed more variation due to prolonged growth prior cell division. Cells of A. alaskana had significantly less width (Mann-Whitney test, $p<0.0001$ ) and significantly less length (Mann-Whitney test, $p<0.0001$ ) compared to A. nordenskioeldii (Figure S3).

Table 2. Average cell sizes $(\mu \mathrm{m}) \pm$ standard deviation and cell size ranges (with $\mathrm{n}=$ number of measured cells in brackets), and maximum population densities \pm standard deviation of the two glacial algae A. alaskana and A. nordenskioeldii are shown.

\begin{tabular}{cccc}
\hline Species & Sample & Cell Width $\times$ Length $(\boldsymbol{\mu m})$ & ${\text { Cells } \mathbf{~ m L}^{-\mathbf{1}}}$ \\
\hline A. alaskana & P39 1 & $8.7 \pm 0.8 \times 12.1 \pm 2.8 ; 7.3-11.6 \times 8.1-20.6(83)$ & - \\
A. alaskana & WP167 & $7.6 \pm 0.3 \times 12.1 \pm 1.9 ; 7-8.4 \times 8.5-17.1(30)$ & $4.77 \times 10^{5} \pm 0.07 \times 10^{5}$ \\
A. alaskana & WP212 & $8.5 \pm 0.7 \times 12.8 \pm 2.7 ; 7.5-10.2 \times 9.4-19.7(22)$ & - \\
A. alaskana & WP251 & $8.4 \pm 0.8 \times 11.4 \pm 2.4 ; 7.0-10.5 \times 8.4-16.3(27)$ & - \\
A. nordenskioeldii & WP210 & $12.9 \pm 1.1 \times 29.4 \pm 6.8 ; 10.7-15.2 \times 19.6-50(19)$ & - \\
A. nordenskioeldii & WP211 & $13.6 \pm 0.8 \times 37.5 \pm 7.6 ; 12.4-14.7 \times 22.1-51(28)$ & $4.8 \times 10^{5} \pm 0.25 \times 10^{5}$ \\
A. nordenskioeldii & WP249 & $13.7 \pm 0.7 \times 28.3 \pm 5.5 ; 12.6-15 \times 20.6-43.4(33)$ & - \\
\hline
\end{tabular}

${ }^{1}$ Published data are from [6].

\subsection{Cultivation Attempts}

Under laboratory conditions, the field collected cells transiently continued for several weeks to grow (including a few cell divisions), the dark vacuolar pigmentation decreased and chloroplast morphology became evident (Figure S4). In the case of A. nordenskioeldii, it resulted in the formation of filaments with up to 64 cells (data not shown). Similarly, A. alaskana developed single cells, short and loose filaments with up to 4 cells. No strain was established.

\subsection{Molecular Taxonomy}

The population of A. nordenskioeldii from the Swiss Alps was 100\% identical with Svalbard ones for the 18S rDNA molecular marker, i.e., compare MW922838 and AF514397.2. Due to the longer 18S rDNA fragment of a newly acquired sequence (2008 bp), the intron close to the 3 '-end of $18 \mathrm{~S}$ rDNA sequence of this species was detected only for the former (accession number MW922838), corresponding by its position to intron group I in Fottea pyrenoidosa SAG 1.88 (1760-2063 in KM020068.1), while the available sequences of polar A. nordenskioeldii (1753 bp long, AF514397.2) and alpine A. alaskana were shorter (1660 bp long, JF430424.1).

The phylogenetic analysis of $18 \mathrm{~S}$ rDNA within the Zygnematales showed that the two investigated glacial algae were very closely related (Figure 2). They formed an independent, well-supported "Ancylonema" clade. The sequence difference in $18 \mathrm{~S}$ rDNA marker was between the two species 3 out of 1552 bp (99.8\% similarity; MW922838 vs. JF430424.1). According to the $r b c \mathrm{~L}$ phylogeny, A. nordenskioeldii and A. alaskana congruently formed a well-supported clade with Mesotaenium sp. AG-2009-1, which was resolved as a part of a larger clade "Mesotaenium 1" (Figure 3). Further members of the Mesotanium 1-clade were Fottea pyrenoidosa SAG 1.88 (from soil in subantarctic Signy Island), Zygogonium ericetorum JH1396 (Austrian Alps) and Mesotaenium cf. chlamydosporum M-2155 (unknown origin). The sequence difference in the $r b c \mathrm{~L}$ marker between the two glacial algae was 6 out of 558 bp (98.9\% similarity; MW922839 vs. MW922840). 


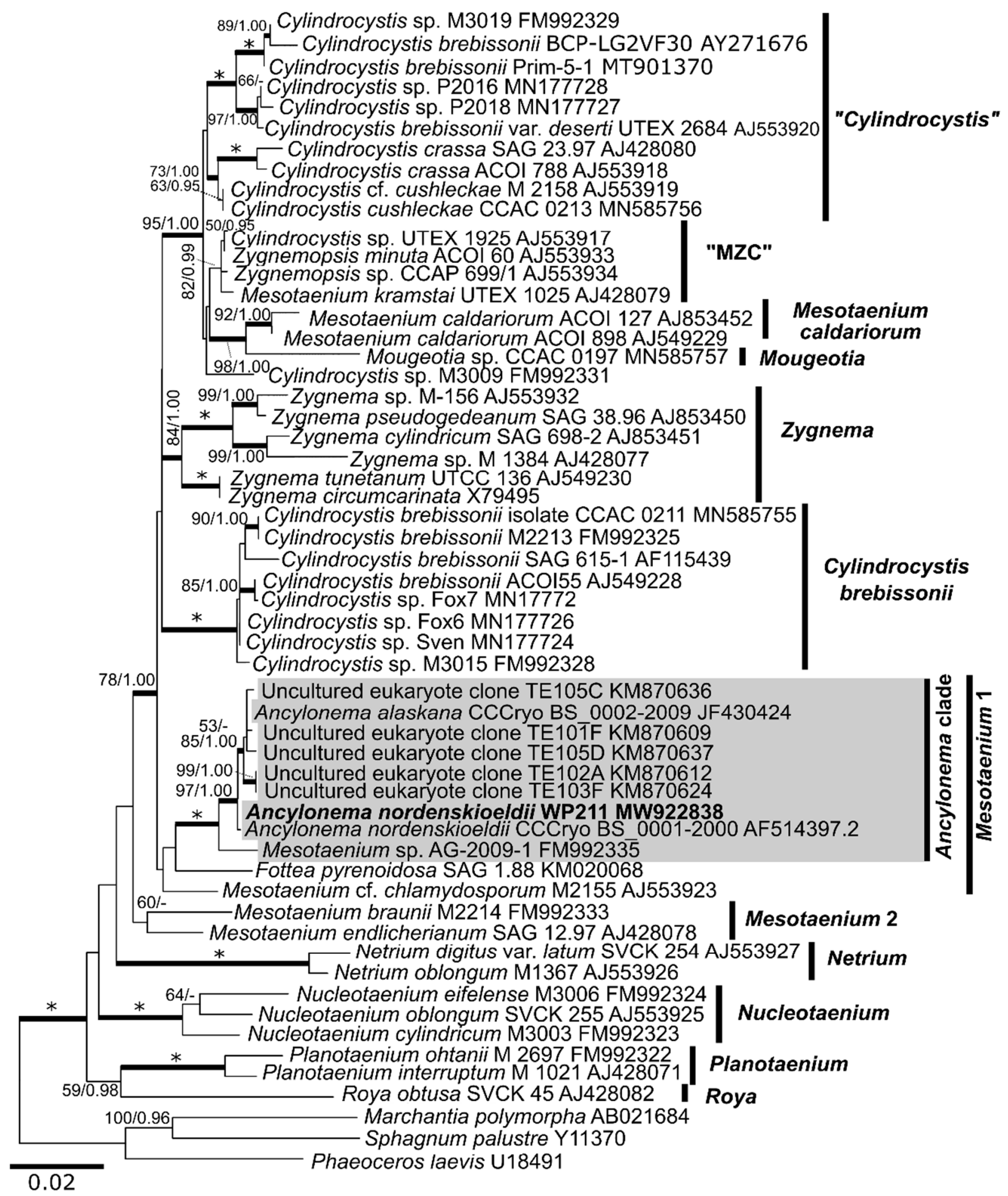

Figure 2. 18S rRNA gene-based maximum-likelihood phylogenetic tree of the Zygnematophyceae. The 'Ancylonema'-clade is highlighted (grey box). All the other labelled clades correspond to [21]. Posterior probabilities ( $\geq 0.95)$ and bootstrap values from maximum likelihood analyses $(\geq 50 \%)$ are shown. Full statistical support $(1.00 / 100)$ is marked with an asterisk. Thick branches represent nodes receiving the highest posterior probability support (1.00). Newly obtained sequence is in bold. Accession numbers, strain or field sample codes are indicated after each species name. 


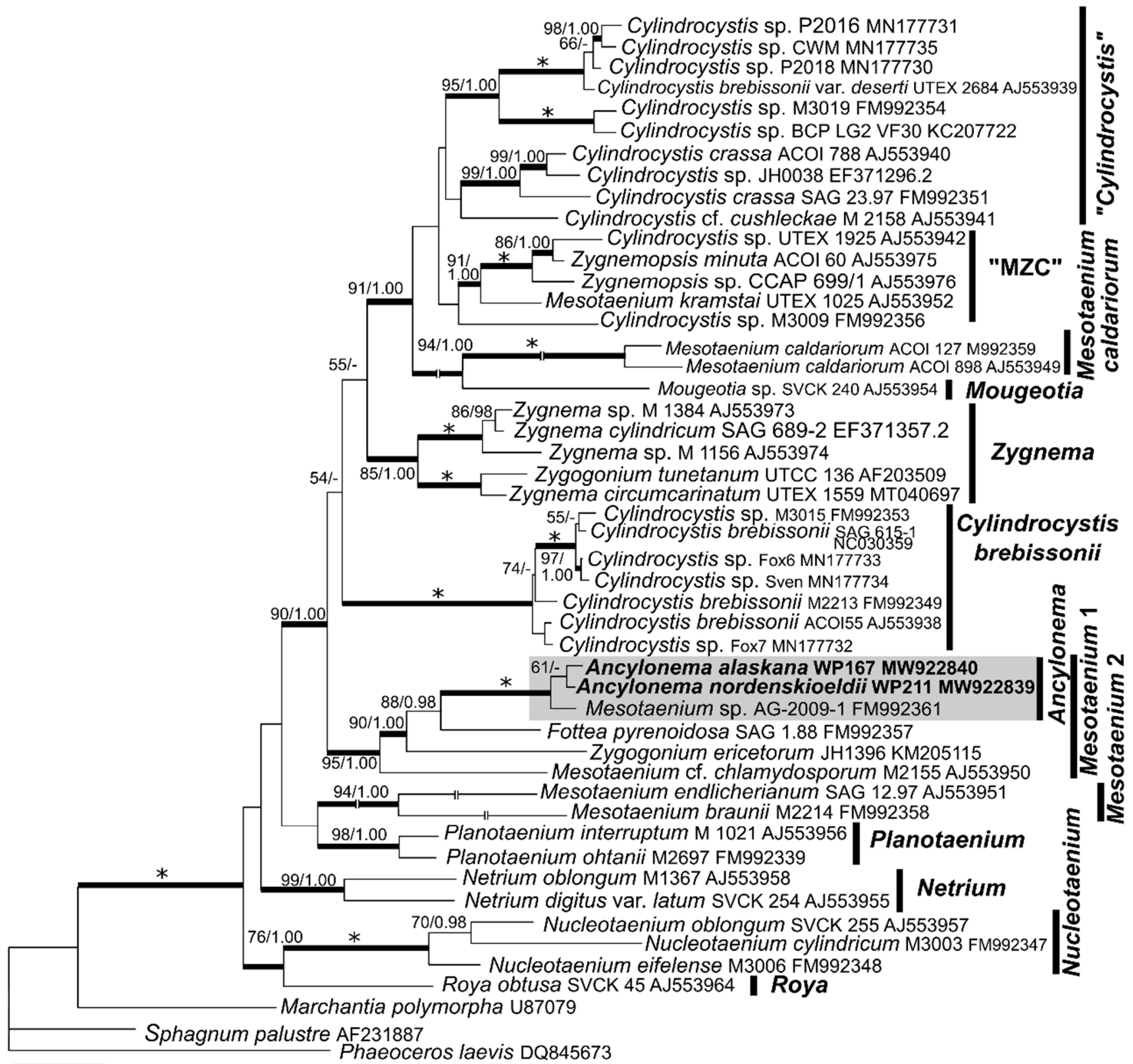

0.07

Figure 3. The $r b c \mathrm{~L}$ gene-based maximum-likelihood phylogenetic tree of selected Zygnematales. The names of clades correspond to [21]. Posterior probabilities ( $\geq 0.95)$ and bootstrap values from maximum likelihood analyses $(\geq 50 \%)$ are shown. Full statistical support (1.00/100) is marked with an asterisk. Thick branches represent nodes receiving the highest posterior probability support (1.00). Newly obtained sequence in bold. Accession numbers, strain or field sample codes are indicated after each species name.

\subsection{Photosynthesis}

To compare the photophysiology of A. alaskana and A. nordenskioeldii, rapid light curves were generated (Figure 4). The maximal rETR achieved at $1500 \mu \mathrm{mol}$ photons $\mathrm{m}^{-2} \mathrm{~s}^{-1}$ was 27 and 26.6, respectively, although a saturation of the light curves was not evident by this highest applied irradiance. The two glacial algae significantly differed in the values alpha (0.22 vs. 0.07) and $\mathrm{I}_{\mathrm{k}}(109 \mathrm{vs.} 452)$. Whilst higher alpha and lower $\mathrm{I}_{\mathrm{k}}$ of $A$. alaskana indicated that its photosystem II is working very effectively at very low irradiations, it remained capable of greater electron transport for a given PAR over the whole measurement range as compared to A. nordenskioeldii. 


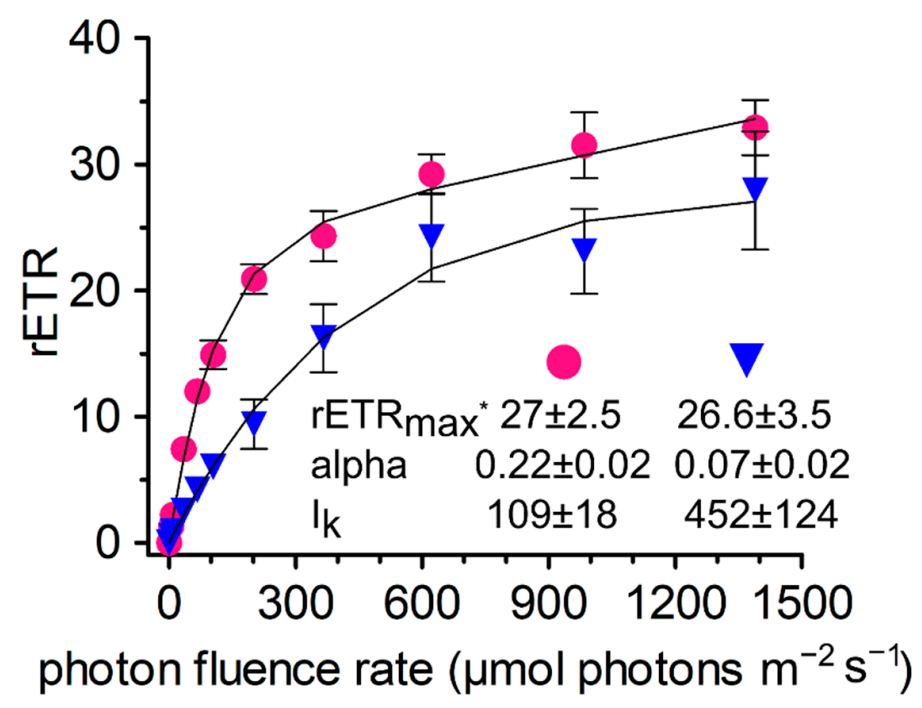

Figure 4. Photosynthetic rapid light curves of Ancylonema alaskana (pink circles) and Ancylonema nordenskioeldii (blue triangles). The effect of increasing photon fluence rates ( $x$-axis) on the relative electron transport rate (rETR; $y$-axis) in chloroplasts was measured with field samples (WP167 and WP211) ( $\mathrm{n}=4, \pm \mathrm{SD})$. The maximal $\mathrm{rETR}$ value achieved at $1500 \mu \mathrm{mol}$ photons $\mathrm{m}^{-2} \mathrm{~s}^{-1}\left(^{*}\right)$. The data points were fitted to the model, assuming no photoinhibition [39].

\subsection{Phenolic Pigments}

The main chromatographic peak of the aqueous extract of $A$. nordenskioeldii had online absorption maxima at 305 and $395 \mathrm{~nm}$ (Figure S5). Mass spectrometry of this compound revealed a molecular weight of $426 \mathrm{~g} \mathrm{~mol}^{-1}$.

\subsection{Shotgun Lipidomic}

Lipidomic profiles of the two Ancylonema species are shown in Figure 5 and described in detail in Table S2. Altogether, 346 molecular species of lipids and 19 lipid subclasses were identified. Triacylglycerols (TAGs) represented the most abundant lipid class of the A. nordenskioeldii and A. alaskana (50.9\% vs. $47.4 \%$ in total lipids). These were followed by sphingolipids ( $28 \%$ vs. $25.2 \%$; five subclasses), glycolipids ( $13.3 \%$ vs. $17.7 \%$; three subclasses), phospholipids ( $4.3 \%$ vs. $6.6 \%$; nine subclasses) and diacylglycerols ( $3.5 \%$ vs. $3.1 \%$ ). Triacylglycerols of the two samples consisted only of molecules with an even number of acyl carbons, i.e., from 42 to 60 . The most frequent were TAGs having 3-9 double bonds. The most abundant TAGs were 50:7, 54:8, 50:5 and 54:9. The most abundant sphingolipids were glycosyl inositol phospho ceramides (GIPCs) with sphingoid bases: t18:1, h24:0 and $\mathrm{t} 18: 1, \mathrm{~h} 24: 1$, followed by glucosylceramide (GlcCers) (t18:1, h24:0 and t18:1, h24:1, i.e., sphingoid bases). The major glycolipids were monogalactosyldiacylglycerol (MGDG) 34:6 and sulfoquinovosyldiacylglycerol (SQDG) 32:0, 34:2, 34:3. The main phospholipids were phosphatidylglycerol (PG) 34:4 and phosphatidylcholine (PC) 36:5. Only small differences in the abundance of TAGs and the main representatives of the other lipid classes were detected between these algal species.

\subsection{Fatty Acid (FA) Composition}

The relative content of FAs (in percentage of total fatty acids) in A. nordenskioeldii (WP211) and A. alaskana (WP251) is shown in Figure 6. FAs from 14 to $20 \mathrm{C}$ were found. Cells accumulated high levels of PUFAs ( $48.8 \%$ and $67.1 \%$ of total lipids, respectively), whereas the content of saturated acids (SAFAs) did not exceed $29 \%$ and $23.8 \%$, respectively (mainly palmitic acid (16:0), i.e., $24.1 \%$ and $22.6 \%$, respectively). The main monounsaturated fatty acid (MUFA) was oleic acid (18:1 (9Z), 21.9\% and 8.3\%). The most abundant PUFAs were linoleic acid (18:2 (9Z,12Z), 9.3\% and 25.5\%), $\alpha$-linolenic acid (18:3 (9Z,12Z,15Z), $18.9 \%$ and 22.93\%), followed by steriadonic acid (18:4 (6Z, 9Z, 12Z, 
$15 \mathrm{Z}), 14.5 \%$ and $2 \%$ ), and hexadecatetraenoic acid (16:4 (4Z, 7Z, 11Z, 13Z), $4.7 \%$ and $0 \%$ ). The total lipid content per dry mass of $A$. nordenskioeldii and A. alaskana was $10.1 \%$ and $12.8 \%$, respectively.

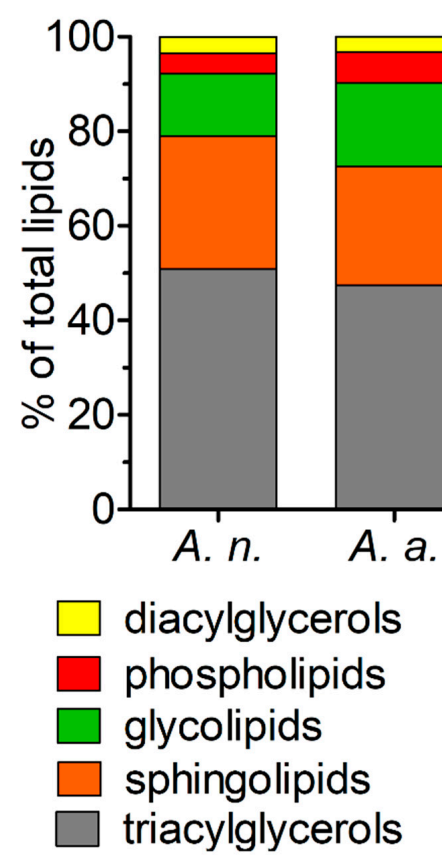

(a)

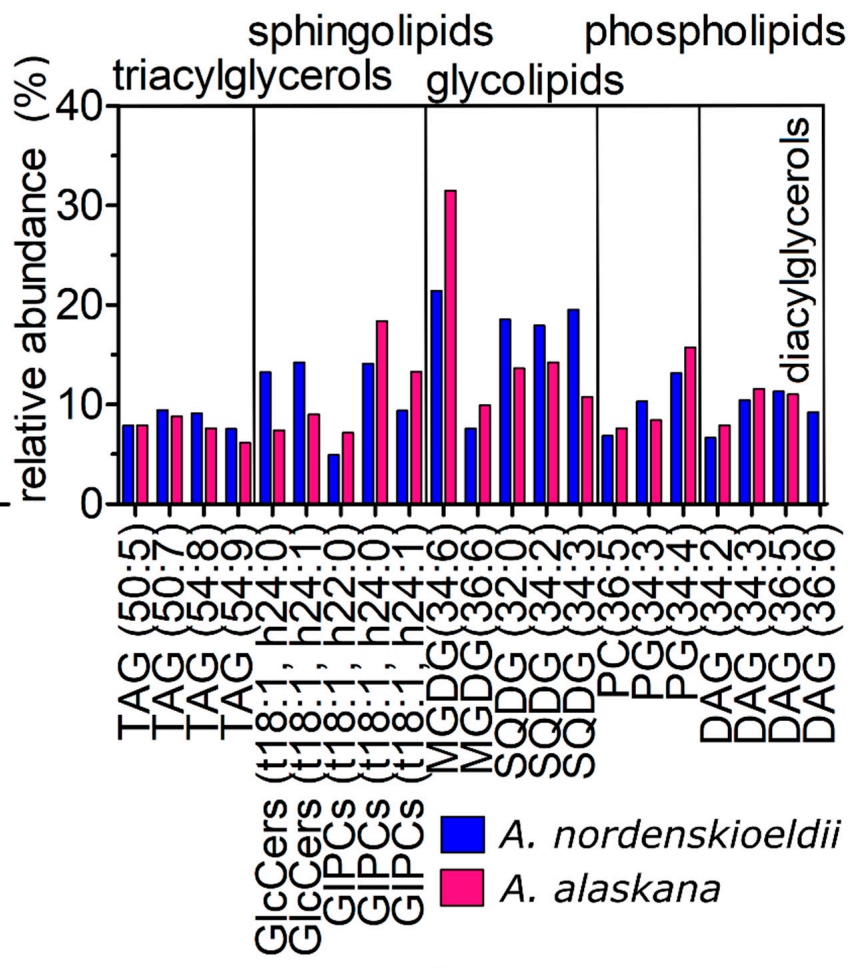

(b)

Figure 5. Cellular lipid composition of Ancylonema nordenskioeldii (WP211) and Ancylonema alaskana (WP167). (a) The relative proportions of lipid classes in (\%) of total lipids. (b) The relative abundance of the most abundant lipid representatives of triacylglycerols (TAGs), sphingolipids (GIPCs, GlcCers), glycolipids (MGDG, SQDG), phospholipids (PG, PC),diacylglycerols (DAGs). The figure (b) shows only lipids that had abundances greater than $7 \%$ in a relevant lipid class.

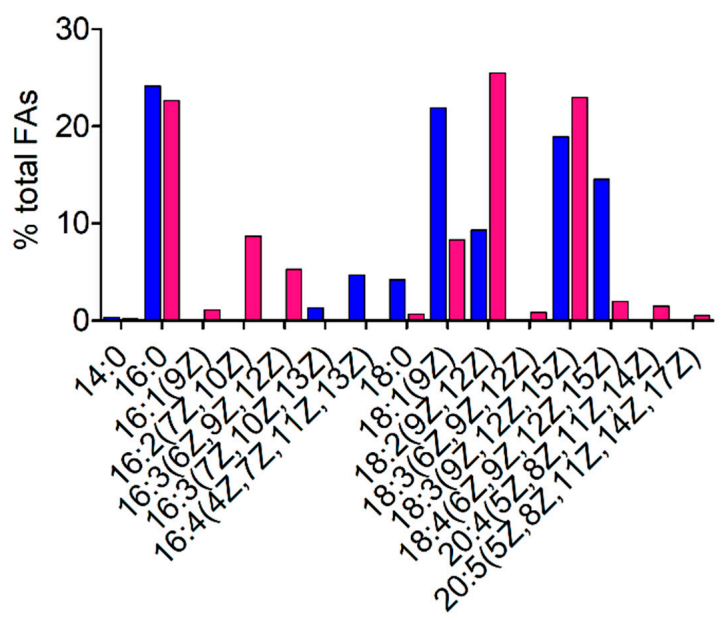

(a)

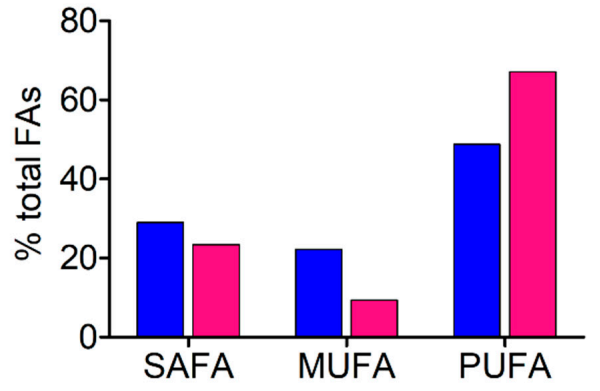

A. nordenskioeldii

A. alaskana

Figure 6. Cellular fatty acid composition Ancylonema nordenskioeldii (blue; WP211) and Ancylonema alaskana (pink; WP251). (a) The relative proportions of fatty acids in (\%) of total fatty acids. (b) The relative proportion of saturated (SAFA), monounsaturated (MUFA), and polyunsaturated (PUFA) fatty acids. The figure (a) shows only fatty acids that had abundances greater than $0.1 \%$ of total FAs. 


\section{Discussion}

\subsection{Geographical Distribution of Glacial Algae}

While A. alaskana seems to be widespread on many glaciers of the Eastern Alps (localities summarized in Table S3) and elsewhere, A. nordenskioeldii was hardly reported from Europe, indicating that it could require certain abiotic conditions to cause blooms. The latter species was initially described from the Greenland Ice Cap [35], where it grows abundantly during summer [16]. Reports of Ancylonema filaments from the southern hemisphere are rare: Southern Patagonia Icefield, Chile [40] and King George Island, Maritime Antarctica [41]. In Central Europe, the first discovery was by Chodat in 1896 at Mont Blanc, France [42]. Recently, a large population was discovered at Morteratsch Glacier, Switzerland [18] and subsequently investigated in this study. This glacier is one of the largest in the Eastern Alps, reaching down to altitudes of about $2.200 \mathrm{~m}$ a.s.l., where a prolonged melting period without snow cover on the ice probably supports $A$. nordenskiöldii in developing its characteristically trichal stages. Nonetheless, it is possible that this species is more widespread than expected, taking various reports of "large" $M$. berggrenii cells into account, which could represent single celled stages of $A$. nordenskioeldii.

The cellular characteristics of $A$. alaskana were similar to those reported previously from polar or high alpine regions such as Antarctica ("small form" in [5]), Himalaya [34], Svalbard [31], Greenland [17,32] and Alaska [28]. However, it remains currently unresolved whether A. alaskana is a single species with cosmopolitan distribution, or a number of similar but distinct unicellular taxa evolved growing on melting ice surfaces.

Also, in the case of A. nordenskioeldii the question of one species with global distribution remains under debate. Despite the lack of strains and marker sequences from field populations of many regions in the world, significant variation in average cell sizes between communities point either to an underestimated biological diversity of zygnematophycean glacial algae or certain levels of ploidy, as suggested by [5]. Moreover, single-celled stages of A. nordenskioeldii (Figure 1f), although already mentioned in the original description [35], may have been morphologically misinterpreted with different species, such as a large form of "M. berggrenii" sensu [8] (e.g., see figure 2C in [13]; and figure 1e in [18]). At Morteratsch Glacier, we noticed scattered filaments of an apparently third species, similar to the description of $A$. nordenskioeldii var. chodatii [43]. However, sequences of this organism are currently not available, but the distinct morphology indicates that these streptophytic organisms form characteristic size classes.

\subsection{Habitat Conditions, Population Densities and Cell Sizes of Glacial Algae}

The irradiation levels, slightly acidic $\mathrm{pH}$ and very low meltwater conductivity at the Swiss glacier were comparable to those at the studied Austrian glacier [6]. In both cases, the populations were sampled close to the glacier terminus, with the Austrian sampling site located $500 \mathrm{~m}$ higher. The population densities of glacial algae at the Austrian and Swiss sites reached values known from polar regions (up to $3 \times 10^{5}$ cells $\mathrm{mL}^{-1}$, SW Greenland Ice Cap, [13]; $1 \times 10^{5}$ cells mL ${ }^{-1}$ Windmill island, Antarctica, [5]) or were higher than these (up to $1.6 \times 10^{4}$ cells $\mathrm{mL}^{-1}$, SE Greenland Ice Cap, [17]). However, these numbers were observations at a given moment in course of the season; episodic variations of physical parameters like precipitation and surface temperature influence the population development and consequently the algal biomass (T. Kohler, Charles University, Czech Republic-pers. observation), as indicated also by ice-core analysis [44]. Furthermore, the extent of blooms is influenced by inorganic nutrient availability in these oligotrophic habitats, which was demonstrated by [31] or [16].

Overall cell sizes were demonstrated here as a significant key in European localities to distinguish $A$. alaskana from $A$. nordenskioeldii. Interestingly, generally smaller $A$. nordenskioeldii were reported from Arctic Svalbard ( $8.1 \pm 1.7 \mu \mathrm{m}$ wide $\times 19.0 \pm 7.8 \mu \mathrm{m}$ long, [11]), these cells were genetically identical for $18 \mathrm{~S}$ rDNA with the Swiss populations. It remains open as to whether the former represents a different, very closely related species, or their smaller sizes are an effect of different abiotic conditions than in the Alps. 


\subsection{Phylogeny and Morphological Traits}

Molecular mechanisms during terrestrialisation of the Zygnematophyceae were highlighted by [45], namely that horizontally acquired genes from soil bacteria regulate cell development and stress response, like in their sister group, the land plants. This could have been a prerequisite for the colonization of wet ice surfaces as well. Nonetheless, the closest non-cryoflora relatives of glacial algae have not been elucidated yet; the majority of Mesotaeniaceae live in semi-terrestrial or aerophytic habitats. The $18 \mathrm{~S}$ rDNA and $r b c \mathrm{~L}$ phylogenies showed a very close relationship between $A$. nordenskioeldii and A. alaskana, pointing to a common ancestor, and they formed the Ancylonema clade. In contrast, the third prominent species of glacial algae, Cylindrocystis brebissonii, is situated in its own zygnematophycean clade which was named after this organism [10].

A. alaskana from Austria was very closely related to four unaffiliated environmental sequences isolated from an Alaskan glacier. Appropriately, this species (respectively its basionym) was initially described from Alaska [28]. The $r b c$ L sequences obtained in this study confirmed the placement of the genus Ancylonema in the larger "Mesotaenium 1"clade sensu [21]. The closest known, non-glacial $18 \mathrm{~S}$ rDNA and $r b c \mathrm{~L}$ sequences belonged to semi-terrestrial Mesotaenium AG-2009-1 isolated from wet rocks in a forest at Eifel, Germany (no strain available; A. Gontscharov, FEB RAS, Vladivostok, Russia-pers. comm.). It was placed into the Ancylonema clade, indicating that this clade is not exclusively glacial algae. The further closest relatives are the high alpine semi-terrestrial alga Zygogonium ericetorum from an intermittent streamlet in the Austrian Alps [46] and Fottea pyrenoidosa SAG 1.88, isolated from soil at subantarctic Signy Island [47]. While the latter had green cells, Zygogonium exhibited striking purple vacuoles [48] caused by phenols in a similar manner to glacial algae.

This study confirms, in accordance with earlier work (e.g., [21]), the polyphyly of Mesotaenium. Traditionally, the chloroplast morphology was crucial to distinguish between genera within the Zygnematales. Mesotaenium was typified by a single, central (axial) plate-like chloroplast (and prior cell division there are two of them) [49]. In contrast, the chloroplast of both Ancylonema species is clearly parietal, from discoid through slightly cup-shaped to flattened-lobed. A. nordenskioeldii was initially described as possessing a single chloroplast per cell [35]. However, the fact that two chloroplasts per cell were observed in this species as well [11] may either suggest that two independent plastids touch each other, or one plastid is almost divided in two parts, held together by a narrow sinus. The latter was described as "Charles bridge" for Cylindrocystis spp. [10]. Such a sinus has not been observed in field material of A. alaskana nor $A$. nordenskioeldii yet, but its presence cannot be excluded.

\subsection{Photosynthesis and Phenols}

Fluorometric photophysiology showed no decline of activity at higher irradiation in A. nordenskioeldii from Switzerland. Using different protocols, no drop of the lightdependent oxygen evolution took place in Arctic populations of filamentous Ancylonema, even at high VIS irradiation of $2000 \mu \mathrm{mol}$ photons $\mathrm{m}^{-2} \mathrm{~s}^{-1}$ and more $[7,12]$. Similarly,

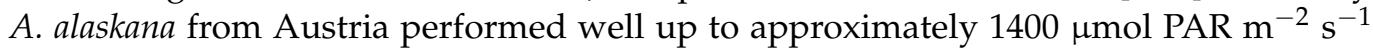
(PreSens optical sensor, [11]). In this study, the two glacial algae differed in their photophysiological behavior at low light, $A$. nordenskioeldii was less effective (lower alpha), compared to A. alaskana. The low alpha and high $\mathrm{I}_{\mathrm{k}}$ of $A$. nordenskioeldii from Switzerland is in agreement with values from a community at the Greenland Ice Sheet [17]. Here, a snapshot of the photophysiology of the two glacial algae was presented, close to the end of the summer season at the two different high Alpine sites (the Gurgler Ferner site for A. alaskana and the Morteratsch Glacier site for A. nordenskioeldii), and further measurements should reveal the variability within and between the species.

Glacial algae appear dark due to the massive accumulation of brownish aqueous phenols [11], and they can account almost 11 times the cellular content of chlorophyll-a [12]. These phenolic pigments, and probably further not yet elucidated components, serve as 
"sun screen" to protect the low-light adapted chloroplasts $\left(\mathrm{I}_{\mathrm{k}} \sim 46 \mu \mathrm{mol}\right.$ photons $\mathrm{m}^{-2}$ $\mathrm{s}^{-1} ;$ [12]. The photoprotective role of phenolic compounds is not exclusive to glacial algae, and is acknowledged also for non-cryoflora members of Zygnematales [50].

The main chromatographic peaks of $A$. nordenskioeldii and A. alaskana were identical by means of retention time, spectral absorption, molecular weight and MS fragmentation pattern [11]. It remains open whether purpurogallin carboxylic acid-6-O- $\beta$-D-glucopyranoside is also prevalent in other zygnematophycean algae with brownish vacuolar pigmentation, i.e., Cylindrocystis brebissonii [51] or Temnogametum iztacalense [52].

\subsection{Lipidomics and Fatty Acids}

Regarding the proportion of the lipid classes and relative proportions of lipid species, a very similar lipidome was found for $A$. nordenskioeldii and $A$. alaskana, reflecting that these species live in the same type of habitat. Here, a snapshot of lipid profiles of natural populations is presented which may be utilized as a reference for future laboratorial strain studies. One of the major thylakoid membrane lipids in algal chloroplasts are glycolipids, namely MGDG, DGDG and SQDG, and phospholipid PG [53]. Microalgae alter their MGDG to DGDG ratio in response to plenty of environmental factors [54]. The MGDG to DGDG ratio for $A$. alaskana and $A$. nordenskioeldii was 5.81 and 5.95 , respectively. In general, a ratio of more than 2 is typical for microalgae grown under balanced growth [54], while the ratio decreases under conditions that are not favorable for growth (such as nutrient starvation, high light intensities) $[54,55]$. Membrane lipid changes play both structural and regulatory roles in plant adaptation and survival when exposed to temperature changes. Under the cold acclimation of a plant, phospholipids PC, glycolipids MGDG and DGDG species that contain two polyunsaturated acyl species, such as 36:5- (18:3-18:2) PC, 34:6- (18:3-16:3) MGDG, and 36:6-DGDG, increased [56]. In the studied glacial algae, these lipid species were the most abundant in their relevant lipid classes. Neutral lipids are represented by tri- and diacylglycerols, and in microalgae are usually deposited in lipid bodies [57]. The most abundant TAGs found in this study $(50: 7,54: 8,54: 9)$ were consistent with the most abundant TAGs found in other cryoflora, namely vegetative stages of in situ snow algal populations [58]. Additionally, sphingolipids are crucial elements in membrane organization where they are supposed to play a major role in raft formation and cross bi-layer lipids integration [59]. These compounds represented here the second most abundant lipid class. The desaturation of sphingolipids may be of essential importance in cold stress responses [60]. Namely, GIPCs and GlcCers dominated this lipid group in the two Ancylonema species, and the same was reported also for leaves of land plants [60].

Generally, the knowledge of FA composition of conjugating algae is limited [61]. In a study on Zygnema [62], young and old cultures were compared. Young ones had only a low content of lipids and the most abundant FAs were palmitic acid, hexadecatrienoic and $\alpha$-linolenic acid. During maturation, the most striking increase was found for oleic acid and linoleic acid, which rose by up to 17-fold and 8-fold, respectively [62]. The snapshot of fatty acid profiles between $A$. nordenskioeldii and $A$. alaskana, taken close to the end of the melting season at alpine glaciers (i.e., September), showed that the predominant fatty acids of both glacial blooms were palmitic acid, oleic acid, linoleic, $\alpha$-linolenic and steriadonic acid. Similarly, these five FAs were the most abundant and accounted altogether for $93.8 \%$ of all fatty acids in the subantarctic soil alga Fottea pyrenoidosa SAG 1.88 [61]. In this work, almost half of the FAs were PUFAs, which are important to keep membrane fluidity at low temperatures [63]. However, the overall cellular content of FAs per dry weight was quite low.

\section{Conclusions}

This study demonstrated that Ancylonema can no longer be regarded as a monotypic genus for a filamentous glacial alga. Except from molecular traits, the main diagnostic feature of this genus are parietal hemispheric, cup-shaped or elongate-lobed chloroplasts while "true" Mesotaenium are characterized by an axial, plate-like chloroplast. Unicellular glacial 
alga $A$. alaskana (here revised from $M$. berggrenii var. alaskanum; previously referred to with an improper Latin termination of the infraspecific name as "alaskana") is widespread in European glaciers, but it has to be tested how much species are actually behind the phenomenon in a global point of view. Physiologically, A. nordenskioeldii and A. alaskana are closely related organisms with similar or identical cellular lipid profiles and identical kind of phenolic secondary pigmentation. The photophysiologies of both species have to be compared with caution since the sampling sites were not the same. Nonetheless, the photosystems of $A$. alaskana were able to use efficiently low irradiances but showed higher ETR rates throughout the rapid light curve as compared to $A$. nordenskioeldii. Finally, the ecological reason why $A$. alaskana dominates communities at central European glaciers and, vice versa, $A$. nordenskioeldii dominates Arctic ones, remains open.

Supplementary Materials: The following are available online at https:/ / www.mdpi.com/article/10 $.3390 /$ microorganisms9051103/s1, Figure S1: Overview of the sampling sites with blooms of glacial algae: (a) Gurgler Ferner, a glacier in Ötztal Valley, Tyrol, Austria (30 August 2017, sample WP167), (b) Morteratsch Glacier in Engadin, Graubünden, Switzerland (22 August 2018, sample WP211). Figure S2: Light micrographs of the Morteratsch Glacier field sample (WP249) showing (a) Ancylonema alaskana (small arrow; former Mesotaenium berggrenii var. alaskanum) and Ancylonema nordenskioeldii (large arrow). (b) Putative Ancylonema nordenskioeldii var. chodatii (arrowhead). Scale $=10 \mu \mathrm{m}$. Figure S3: Comparison of $(\mathrm{a}, \mathrm{c})$ cell widths and $(\mathrm{b}, \mathrm{d})$ cell lengths between Ancylonema nordenskioeldii (A. n.; WP210, $\mathrm{n}=19 ; \mathrm{WP} 211, \mathrm{n}=28 ; \mathrm{WP} 249, \mathrm{n}=33$ ) and Ancylonema alaskana (A. a.; P39, $\mathrm{n}=83$; $\mathrm{WP167}, \mathrm{n}=30$; WP213, $\mathrm{n}=22$; WP251, $\mathrm{n}=27$ ). Details of sample locations are listed in Table 2. Figure S4: Light micrographs of aged field samples kept for a prolonged period under laboratorial conditions, showing (a-e) Ancylonema alaskana WP251 and (f, g) Ancylonema nordenskioeldii WP211. Ancylonema alaskana with gone vacuolar pigmentation: (a) prior division of the chloroplast and the pyrenoid (right cell); (b) just after the chloroplasts division; (c) arrowhead indicates the circle pyrenoid; (d) asterisks point to formation of the new wall (septum); (e) separation of the two young cells (i.e., a chain fragmentation), the fully developed septum (large arrow), single nucleus (n; behind the chloroplast). Ancylonema nordenskioeldii with altered vacuolar, ochre pigmentation: (f) Arrowhead indicates the circle pyrenoid. Actively dividing cells resulting in temporal presence of the two parietal partly lobed chloroplasts per each cell in filament, central translucent area shows the nucleus $(n) ;(\mathrm{g})$ an old filament with a single chloroplast per cell and striking vacuolization. Scale: $10 \mu \mathrm{m}$. Figure S5: (a) high-performance liquid chromatography (HPLC)-chromatogram (at $280 \mathrm{~nm}$ ) of a $20 \%$ ethanolic extract of Ancylonema nordenskioeldii field sample from Morteratsch Glacier, acquired with a diode array detector. Inserts: HPLC online spectra (b) second major peak (likely gallic acid glycoside) and (c) first major peak (likely purpurogallin carboxylic acid-6-O- $\beta$-Dglucopyranoside). Table S1: List of primers used for amplification of $18 \mathrm{~S}$ rRNA gene (18S) and $r b c \mathrm{~L}$ markers (F, forward; R, reverse). Table S2: List of 346 molecular species of lipids identified by shotgun analysis for Ancylonema nordenskioeldii (WP211) and Ancylonema alaskana (WP167). Table S3: List of glaciers in the Austrian Alps with occurrence of Ancylonema alaskana. No filaments of Ancylonema nordenskioeldii were found in all cases.

Author Contributions: Conceptualization, L.P. and D.R.; Data curation, L.P.; Formal analysis, L.P.; Funding acquisition, L.N. and D.R.; Investigation, L.P., T.Ǩ. and D.R.; Project administration, L.N. and D.R.; Resources, L.P. and D.R.; Supervision, D.R.; Visualization, L.P.; Writing-original draft, L.P.; Writing - review and editing, L.P. and D.R. All authors have read and agreed to the published version of the manuscript.

Funding: This research was funded by the Czech Science Foundation (GACR), grant number 1802634S, granted to L.N. and L.P. The Austrian Science Fund (FWF) P34073, granted to D.R. The INTEREXCELLENCE project, grant number LTAIN19139, granted to L.N., and the institutional long-term research plan of the Institute of Botany of Czech Academy of Sciences, RVO 67985939. L.P. has been supported by Charles University Research Centre program No. 204069.

Institutional Review Board Statement: Not Applicable.

Informed Consent Statement: Not Applicable. 
Data Availability Statement: The obtained sequences (MW922838; MW922839; MW922840) were submitted in GenBank.

Acknowledgments: We thank Andreas Holzinger for providing laboratorial access at the University of Innsbruck, Austria, and for lending the PAM 2500. Open Access Funding by the Austrian Science Fund (FWF).

Conflicts of Interest: The authors declare no conflict of interest. The funders had no role in the design of the study; in the collection, analyses, or interpretation of data; in the writing of the manuscript; or in the decision to publish the results.

\section{References}

1. Anesio, A.M.; Lutz, S.; Chrismas, N.A.M.; Benning, L.G. The microbiome of glaciers and ice sheets. NPJ Biofilms Microbiomes. 2017, 3, 10. [CrossRef] [PubMed]

2. Boetius, A.; Anesio, A.M.; Deming, J.W.; Mikucki, J.A.; Rapp, J.Z. Microbial ecology of the cryosphere: Sea ice and glacial habitats. Nat. Rev. Microbiol. 2015, 13, 677-690. [CrossRef] [PubMed]

3. Hotaling, S.; Hood, E.; Hamilton, T.L. Microbial ecology of mountain glacier ecosystems: Biodiversity, ecological connections and implications of a warming climate. Environ. Microbiol. 2017, 19, 2935-2948. [CrossRef]

4. Hoham, R.W.; Remias, D. Snow and Glacial Algae: A Review. J. Phycol. 2020, 56, 264-282. [CrossRef]

5. Ling, H.U.; Seppelt, R.D. Snow algae of the Windmill Islands, continental Antarctica. Mesotaenium berggrenii (Zygnematales, Chlorophyta) the alga of grey snow. Antarct. Sci. 1990, 2, 143-148. [CrossRef]

6. Remias, D.; Holzinger, A.; Lütz, C. Physiology, ultrastructure and habitat of the ice alga Mesotaenium berggrenii (Zygnemaphyceae, Chlorophyta) from glaciers in the European Alps. Phycologia 2009, 48, 302-312. [CrossRef]

7. Remias, D.; Holzinger, A.; Aigner, S.; Lütz, C. Ecophysiology and ultrastructure of Ancylonema nordenskiöldii (Zygnematales, Streptophyta), causing brown ice on glaciers in Svalbard (high arctic). Polar Biol. 2012, 35, 899-908. [CrossRef]

8. Kol, E. Kryobiologie. Biologie und Limnologie des Schnees und Eises. I. Kryovegetation. In Die Binnengewässer; Elster, H.J., Ohle, W., Eds.; Band XXIV; Schweizerbart'sche Verlagsbuchhandlung: Stuttgart, Germany, 1968.

9. Williamson, C.J.; Cameron, K.A.; Cook, J.M.; Žárský, J.D.; Stibal, M.; Edwards, A. Glacier algae: A dark past and a darker future. Front. Microbiol. 2019, 10, 524. [CrossRef]

10. Barcytè, D.; Pilátová, J.; Mojzeš, P.; Nedbalová, L. The Arctic Cylindrocystis (Zygnematophyceae, Streptophyta) green algae are genetically and morphologically diverse and exhibit effective accumulation of polyphosphate. J. Phycol. 2020, 56, 217-232. [CrossRef]

11. Remias, D.; Schwaiger, S.; Aigner, S.; Leya, T.; Stuppner, H.; Lütz, C. Characterization of an UV- and VIS-absorbing, purpurogallinderived secondary pigment new to algae and highly abundant in Mesotaenium berggrenii (Zygnematophyceae, Chlorophyta), an extremophyte living on glaciers. FEMS Microbiol. Ecol. 2012, 79, 638-648. [CrossRef] [PubMed]

12. Williamson, C.J.; Cook, J.; Tedstone, A.; Yallop, M.; McCutcheon, J.; Poniecka, E.; Campbell, D.; Irvine-Fynn, T.; McQuaid, J.; Tranter, M.; et al. Algal photophysiology drives darkening and melt of the Greenland Ice Sheet. Proc. Natl. Acad. Sci. USA 2020, 117, 5694-5705. [CrossRef] [PubMed]

13. Yallop, M.L.; Anesio, A.M.; Perkins, R.G.; Cook, J.; Telling, J.; Fagan, D.; MacFarlane, J.; Stibal, M.; Barker, G.; Bellas, C.; et al. Photophysiology and albedo-changing potential of the ice algal community on the surface of the Greenland ice sheet. ISME J. 2012, 6, 2302-2313. [CrossRef]

14. Lutz, S.; Anesio, A.M.; Jorge Villar, S.E.; Benning, L.G. Variations of algal communities cause darkening of a Greenland glacier. FEMS Microbiol. Ecol. 2014, 89, 402-414. [CrossRef] [PubMed]

15. Stibal, M.; Box, J.E.; Cameron, K.A.; Langen, P.L.; Yallop, M.L.; Mottram, R.H.; Khan, A.L.; Molotch, N.P.; Chrismas, N.A.M.; Quaglia, F.C.; et al. Algae drive enhanced darkening of bare ice on the Greenland ice sheet. Geophys. Res. Lett. 2017. [CrossRef]

16. McCutcheon, J.; Lutz, S.; Williamson, C.; Cook, J.M.; Tedstone, A.J.; Vanderstraeten, A.; Wilson, S.A.; Stockdale, A.; Bonneville, S.; Anesio, A.M.; et al. Mineral phosphorus drives glacier algal blooms on the Greenland Ice Sheet. Nat. Commun. 2021, 12, 570. [CrossRef]

17. Williamson, C.; Anesio, A.M.; Cook, J.; Tedstone, A.; Poniecka, E.; Holland, A.; Fagan, D.; Tranter, M.; Yallop, M. Ice algal bloom development on the surface of the Greenland Ice Sheet. FEMS Microbiol. Ecol. 2018, 94, fiy025. [CrossRef] [PubMed]

18. Di Mauro, B.; Garzonio, R.; Baccolo, G.; Franzetti, A.; Pittino, F.; Leoni, B.; Remias, D.; Colombo, R.; Rossini, M. Glacier algae foster ice-albedo feedback in the European Alps. Sci. Rep. 2020, 10, 4739. [CrossRef]

19. Procházková, L.; Leya, T.; Křižková, H.; Nedbalová, L. Sanguina nivaloides and Sanguina aurantia gen. et spp. nov. (Chlorophyta): The taxonomy, phylogeny, biogeography and ecology of two newly recognised algae causing red and orange snow. FEMS Microbiol. Ecol. 2019, 95, fiz064. [CrossRef]

20. Procházková, L.; Remias, D.; Řezanka, T.; Nedbalová, L. Chloromonas nivalis subsp. tatrae, subsp. nov. (Chlamydomonadales, Chlorophyta): Re-examination of a snow alga from the High Tatra Mountains (Slovakia). Fottea 2018, 18, 1-18. [CrossRef]

21. Gontcharov, A.A.; Melkonian, M. Molecular phylogeny and revision of the genus Netrium (Zygnematophyceae, Streptophyta): Nucleotaenium gen. nov. J. Phycol. 2010, 46, 346-362. [CrossRef]

22. Posada, D. jModelTest: Phylogenetic model averaging. Mol. Biol. Evol. 2008, 25, 1253-1256. [CrossRef] [PubMed] 
23. Nedbalová, L.; Mihál, M.; Kvíderová, J.; Procházková, L.; Řezanka, T.; Elster, J. Identity, ecology and ecophysiology of planktic green algae dominating in ice-covered lakes on James Ross Island (northeastern Antarctic Peninsula). Extremophiles. 2017, 21, 187-200. [CrossRef] [PubMed]

24. Bligh, E.G.; Dyer, W.J. A rapid method of total lipid extraction and purification. Can. J. Biochem. Phys. 1959, 37, 911-917. [CrossRef] [PubMed]

25. Kates, M.; Volcani, B.E. Biosynthetic pathways for phosphatidylsulfocholine, the sulfonium analogue of phosphatidylcholine. In Biological and Environmental Chemistry of DMSP and Related Sulfonium Compounds, in Diatoms; Kiene, R.P., Visscher, P.T., Keller, M.D., Kirst, G.O., Eds.; Springer: Boston, MA, USA, 1996; pp. 109-119.

26. Saunders, R.D.; Horrocks, L.A. Simultaneous extraction and preparation for high-performance liquid chromatography of prostaglandins and phospholipids. Anal. Biochem. 1984, 143, 71-75. [CrossRef]

27. Dembitsky, V.M.; Řezanka, T.; Rozentsvet, O.A. Lipid composition of three macrophytes from the Caspian Sea. Phytochemistry 1993, 33, 1015-1019. [CrossRef]

28. Kol, E. The snow and ice algae of Alaska. Smithson. Misc. Collect. 1942, 101, 1-36.

29. Takeuchi, N. The altitudinal distribution of snow algae on an Alaska glacier (Gulkana Glacier in the Alaska Range). Hydrol. Process. 2001, 15, 3447-3459. [CrossRef]

30. Darcy, S.K.; Schmidt, J.L. Phylogeny of ulotrichalean algae from extreme high-altitude and high-latitude ecosystems. Polar Biol. 2015, 38, 689-697.

31. Takeuchi, N.; Tanaka, S.; Irvine-Fynn, T.D.L.; Rassner, S.M.E.; Edwards, A. Variations in phototroph communities on the ablating bare-ice surface of glaciers on Brøggerhalvøya, Svalbard. Front. Earth Sci. 2019, 7, 4. [CrossRef]

32. Lutz, S.; McCutcheon, J.; McQuaid, J.B.; Benning, L.G. The diversity of ice algal communities on the Greenland Ice Sheet as revealed by oligotyping. Microbial. Genomics. 2018, 4, e000159. [CrossRef]

33. Takeuchi, N.; Uetake, J.; Fujita, K.; Aizen, V.B.; Nikitin, S.D. A snow algal community on Akkem Glacier in the Russian Altai Mountains. Ann. Glaciol. 2006, 43, 378-384. [CrossRef]

34. Yoshimura, Y.; Kohshima, S.; Ohtani, S. A community of snow algae on a Himalayan glacier: Change of algal biomass and community structure with altitude. Arctic Alpine Res. 1997, 29, 126-137. [CrossRef]

35. Berggren, S. Alger från Grönlands inlandis. In Öfversigt af Kongl. Vetenskaps-Akademiens Förhandlingar; P. A. Norstedt \& Söner: Stockholm, Sweden, 1871; pp. 293-297.

36. Wittrock, B. Om snöns och isens flora, särskildt i de arktiska trakterna. In Studier och Forskningar Föranledda af Mina Resor $i$ Hoga Norden; Nordenskiöld, A.E., Ed.; F. \& G. Beijers Forlag: Stockholm, Sweden, 1883; pp. 63-124.

37. Lagerheim, G. Die Schnee Flora des Pichincha. Ein Beitrag zur Kenntnis der Nivalen Algen und Pilzen. Ber. der Dtsch. Bot. Gessellschaft. 1892, 10, 517-534.

38. Turland, N.J.; Wiersema, J.H.; Barrie, F.R.; Greuter, W.; Hawksworth, D.L.; Herendeen, P.S.; Knapp, S.; Kusber, W.-H.; Li, D.-Z.; Marhold, K.; et al. (Eds.) International Code of Nomenclature For algae, Fungi, and Plants (Shenzhen Code) Adopted by the Nineteenth International Botanical Congress Shenzhen, China, July 2017; Regnum Veg. Glashütten 159; Koeltz Botanical Books: Glashütten, Germany, 2018. [CrossRef]

39. Webb, W.L.; Newton, M.; Starr, D. Carbon dioxide exchange of Alnus rubra. A mathematical model. Oecologia. 1974, 17, $281-291$. [CrossRef] [PubMed]

40. Takeuchi, N.; Kohshima, S. A snow algal community on Tyndall Glacier in the Southern Patagonia Icefield, Chile. Arctic Alpine Res. 2004, 36, 92-99. [CrossRef]

41. Komárek, O.; Komárek, J. Contribution to the taxonomy and ecology of green cryosestic algae in the summer season 1995-96 at King George Island, S. Shetland Islands. Nova Hedwig. Beiheft. 2001, 123, 121-140.

42. Kol, E. Über roten and grünen Schnee der Alpen. Verh Intern. Ver. Limnol. 1961, XIV, 912-917. [CrossRef]

43. Krieger, W. Die Desmidiaceen Europas mit Berücksichtigung der aussereuropäischen Arten. Band 13. Abteilung 1, Teil 1, Lieferung 1 of Dr. L. Rabenhorst's Kryptogamen-Flora von Deutschland, Österreich und der Schweiz; Akademische Verlagsgeselschaft M.B.H.: Leipzig, Germany, 1933.

44. Yoshimura, Y.; Kohshima, S.; Takeuchi, N.; Seko, K.; Fujita, K. Himalayan ice-core dating with snow algae. J. Glaciol. 2000, 46, 335-340. [CrossRef]

45. Cheng, S.; Xian, W.; Fu, Y.; Marin, B.; Keller, J.; Wu, T.; Sun, W.; Li, X.; Xu, Y.; Zhang, Y.; et al. Genomes of subaerial Zygnematophyceae provide insights into land plant evolution. Cell 2019, 179, 1057-1067.e14. [CrossRef]

46. Stancheva, R.; Hall, J.D.; Herburger, K.; Lewis, L.A.; Mccourt, R.M.; Sheath, R.G. Phylogenetic position of Zygogonium ericetorum (Zygnematophyceae, Charophyta) from a high alpine habitat and ultrastructural characterization of unusual aplanospores. J. Phycol. 2014, 803, 790-803. [CrossRef]

47. Broady, P.A. Six new species of terrestrial algae from Signy Island, South Orkney Islands, Antarctica. Brit. Phycol. J. 1976, 11, 387-405. [CrossRef]

48. Herburger, K.; Remias, D.; Holzinger, A. The green alga Zygogonium ericetorum (Zygnematophyceae, Charophyta) shows high iron and aluminium tolerance: Protection mechanisms and photosynthetic performance. FEMS Microbiol. Ecol. 2016, 92, 1-15. [CrossRef] [PubMed]

49. Nägeli, C. Gattungen einzelliger Algen, physiologisch und systematisch bearbeitet. Neue Denkschr. der Allg Schweiz. Gesellschaft für die Gesammten Naturwissenschaften. 1849, 10, 1-139. 
50. O'Neal, S.W.; Hoover, A.M. Comparison of UVB effects on growth and induction of UVB screening compounds in isolates of metaphytic algae from temperate zone streams and ponds. J. Phycol. 2018, 54, 818-828. [CrossRef]

51. Nedbalová, L.; Sklenář, P. New records of snow algae from the Andes of Ecuador. Arnaldoa. 2008, 15, 17-20.

52. Garduño-Solórzano, G.; Martínez-García, M.; Scotta Hentschke, G.; Lopes, G.; Castelo Branco, R.; Vasconcelos, V.M.O.; Campos, J.E.; López-Cano, R.; Quintanar-Zúñiga, R.E. The phylogenetic placement of Temnogametum (Zygnemataceae) and description of Temnogametum iztacalense sp. nov., from a tropical high mountain lake in Mexico. Eur. J. Phycol. 2020, 56, 1-15. [CrossRef]

53. Kalisch, B.; Dörmann, P.; Hölzl, G. DGDG and Glycolipids in Plants and Algae. In Lipids in Plant and Algae Development. Subcellular Biochemistry; Nakamura, Y., Li-Beisson, Y., Eds.; Springer: Cham, Switzerland, 2016; pp. 51-83.

54. Mock, T.; Kroon, B.M.A. Photosynthetic energy conversion under extreme conditions-II: The significance of lipids under light limited growth in Antarctic sea ice diatoms. Phytochemistry 2002, 61, 41-51. [CrossRef]

55. Lukeš, M.; Procházková, L.; Shmidt, V.; Nedbalová, L.; Kaftan, D. Temperature dependence of photosynthesis and thylakoid lipid composition in the red snow alga Chlamydomonas cf. nivalis (Chlorophyceae). FEMS Microbiol. Ecol. 2014, 89, 303-315. [CrossRef]

56. Wang, X.; Li, W.; Li, M.; Welti, R. Profiling lipid changes in plant response to low temperatures. Physiol. Plantarum. 2006, 126, 90-96. [CrossRef]

57. Holzinger, A.; Roleda, M.Y.; Lütz, C. The vegetative arctic freshwater green alga Zygnema is insensitive to experimental UV exposure. Micron 2009, 40, 831-838. [CrossRef]

58. Řezanka, T.; Nedbalová, L.; Procházková, L.; Sigler, K. Lipidomic profiling of snow algae by ESI-MS and silver-LC/APCI-MS Phytochemistry 2014, 100, 34-42. [CrossRef] [PubMed]

59. Gronnier, J.; Germain, V.; Gouguet, P.; Cacas, J.L.; Mongrand, S. GIPC: Glycosyl inositol phospho ceramides, the major sphingolipids on earth. Plant Signal. Behav. 2016, 11, 1-7. [CrossRef] [PubMed]

60. Markham, J.E.; Li, J.; Cahoon, E.B.; Jaworski, J.G. Separation and identification of major plant sphingolipid classes from leaves. J. Biol. Chem. 2006, 281, 22684-22694. [CrossRef] [PubMed]

61. Lang, I.; Hodač, L.; Friedl, T.; Feussner, I. Fatty acid profiles and their distribution patterns in microalgae: A comprehensive analysis of more than 2000 strains from the SAG culture collection. BMC Plant Biol. 2011, 11, 124. [CrossRef] [PubMed]

62. Pichrtová, M.; Arc, E.; Stöggl, W.; Kranner, I.; Hájek, T.; Hackl, H.; Holzinger, A. Formation of lipid bodies and changes in fatty acid composition upon pre-akinete formation in Arctic and Antarctic Zygnema (Zygnematophyceae, Streptophyta) strains. FEMS Microbiol. Ecol. 2016, 92, fiw096. [CrossRef] [PubMed]

63. Morgan-Kiss, R.M.; Priscu, J.C.; Pocock, T.; Gudynaite-Savitch, L.; Huner, N.P.A. Adaptation and acclimation of photosynthetic microorganisms to permanently cold environments. Microbiol. Mol. Biol. R. 2006, 70, 222-252. [CrossRef] [PubMed] 